\title{
Phospholipid Scramblase-1-Induced Lipid Reorganization Regulates Compensatory Endocytosis in Neuroendocrine Cells
}

\author{
Stéphane Ory, ${ }_{1}^{1}$ Mara Ceridono, ${ }^{1}$ Fanny Momboisse, ${ }^{1}$ Sébastien Houy, ${ }^{1}$ Sylvette Chasserot-Golaz, ${ }^{1}$ Dimitri Heintz, ${ }^{2}$ \\ Valérie Calco, ${ }^{1}$ Anne-Marie Haeberlé, ${ }^{1}$ Flor A. Espinoza, ${ }^{3,4}$ Peter J. Sims,${ }^{5}$ Yannick Bailly, ${ }^{1}$ Marie-France Bader, ${ }^{1}$ \\ and Stéphane Gasman ${ }^{1}$ \\ ${ }^{1}$ Institut des Neurosciences Cellulaires et Intégratives, Centre National de la Recherche Scientifique (Unité Propre de Recherche 3212) and Université de \\ Strasbourg, 67084 Strasbourg, France, ${ }^{2}$ Institut de Biologie Moléculaire des plantes, Plateforme Métabolomique, Centre National de la Recherche \\ Scientifique (Unité Propre de Recherche 2357) and Université de Strasbourg, 67083 Strasbourg, France, ${ }^{3}$ Department of Pathology, University of New \\ Mexico Albuquerque, Albuquerque, New Mexico 87131-0001, ${ }^{4}$ Department of Mathematics and Statistics, Kennesaw State University, Kennesaw, Georgia \\ 30144, and ${ }^{5}$ University of Rochester Medical Center, School of Medicine and Dentistry, Rochester, New York 14642
}

Calcium-regulated exocytosis in neuroendocrine cells and neurons is accompanied by the redistribution of phosphatidylserine (PS) to the extracellular space, leading to a disruption of plasma membrane asymmetry. How and why outward translocation of PS occurs during secretion are currently unknown. Immunogold labeling on plasma membrane sheets coupled with hierarchical clustering analysis demonstrate that PS translocation occurs at the vicinity of the secretory granule fusion sites. We found that altering the function of the phospholipid scramblase-1 (PLSCR-1) by expressing a PLSCR-1 calcium-insensitive mutant or by using chromaffin cells from PLSCR-1 ${ }^{-I-}$ mice prevents outward translocation of PS in cells stimulated for exocytosis. Remarkably, whereas transmitter release was not affected, secretory granule membrane recapture after exocytosis was impaired, indicating that PLSCR-1 is required for compensatory endocytosis but not for exocytosis. Our results provide the first evidence for a role of specific lipid reorganization and calcium-dependent PLSCR-1 activity in neuroendocrine compensatory endocytosis.

\section{Introduction}

Neurons and neuroendocrine cells secrete neurotransmitters and hormones through calcium-regulated exocytosis. The ultimate step involves fusion of secretory vesicles with the plasma membrane, leading to the release of intravesicular products into the extracellular space. To keep the cell surface constant, exocytosis must be followed by a compensatory membrane retrieval process. Yet, in neuroendocrine cells and neurons, we and others have

Received July 31, 2012; revised Dec. 21, 2012; accepted Jan. 5, 2013.

Author contributions: S.O., M.C., F.M., S.C.-G., D.H., F.A.E., Y.B., M.-F.B., and S.G. designed research; S.O., M.C., F.M., S.H., S.C.-G., D.H., V.C., A.-M.H., F.A.E., Y.B., and S.G. performed research; P.J.S. contributed unpublished reagents/analytic tools; S.O., M.C., F.M., S.H., S.C.-G., D.H., V.C., A.-M.H., F.A.E., P.J.S., Y.B., M.-F.B., and S.G. analyzed data; S.O., D.H., M.-F.B., and S.G. wrote the paper.

This work was supported by Agence Nationale de la Recherche Grant ANR-07-JCIC-088-01 and Association pour la Recherche sur le Cancer Grant ARC 1055 to S.G. and by Fondation pour la Recherche Médicale Fellowship to M.C. This work was supported in part by European Mouse Mutant Archive service under the European Union contract Grant Agreement 227490 of the EC FP7 Capacities Specific Programme. We thank Dr. M. Malacombe for setting up preliminary experiments; T. Thahouly for technical assistance; Drs. H. DeWitt and J.S. Schonn for sharing their technique for culturing mouse chromaffin cells; and Plateforme "Imagerie Cellulaire de Strasbourg Esplanade" (IFR 37des Neurosciences), especially Valérie Demais, for her excellent technical assistance in electron microscopy on plasma membrane sheets preparations.

The authors declare no competing financial interests.

Correspondence should be addressed to either Dr. Stéphane Gasman or Dr. Stéphane Ory, Institut des Neurosciences Cellulaires et Intégratives, Centre National de la Recherche Scientifique (Unité Propre de Recherche 3212) and Université de Strasbourg, 5 rue Blaise Pascal, 67084 Strasbourg, France, E-mail: gasman@inci-cnrs.unistra.fr or ory@inci-cnrs.unistra.fr.

DOI:10.1523/JNEUROSCI.3654-12.2013

Copyright $\odot 2013$ the authors $\quad 0270-6474 / 13 / 333545-12 \$ 15.00 / 0$ recently demonstrated that, after full fusion exocytosis, secretory vesicle/granule components are maintained together at the plasma membrane before being selectively recaptured by endocytosis (Opazo and Rizzoli, 2010; Opazo et al., 2010; Ceridono et al., 2011). However, the molecular machinery underlying segregation and recapture of vesicle membrane components remain unsolved issues.

The dynamics of membrane lipids are crucial for a wide variety of cellular functions. One central feature of cell membranes is the asymmetric distribution of phospholipids between the leaflets. In the plasma membrane, phosphatidylserine (PS) and phosphatidylethanolamine $(\mathrm{PE})$ reside in the inner cytoplasmic leaflet whereas phosphatidylcholine and sphingomyelin are located in the outer leaflet (van Meer et al., 2008). In nonapoptotic cells, several biological functions are accompanied by a disruption of this phospholipid asymmetry, resulting in the externalization of PS in the outer leaflet of the plasma membrane (Ikeda et al., 2006). This is the case for calcium-regulated exocytosis in neuroendocrine chromaffin and PC12 cells as well as in neurons (Lee et al., 2000; Malacombe et al., 2006; Ceridono et al., 2011). How and why phospholipid asymmetry collapses during secretion are currently unknown. The functional importance of lipid scrambling for secretion and efficiency of the exocytotic machinery has been investigated but led to controversial results with alternatively a critical or no function of PS exposure in exocytosis (Kato et al., 2002; Acharya et al., 2006; Smrz et al., 2008). On the other 
hand, PS contributes substantially to the negative charge of the inner leaflet of the plasma membrane, and its local redistribution may have consequences, such as the formation of lipid platforms, which could retain granular membrane components awaiting retrieval or recruit signaling complexes involved in endocytosis (Manno et al., 2002; Yeung et al., 2008).

The aim of the present work was to investigate the functional importance of PS egress to the cell surface during regulated exocytosis and compensatory endocytosis. By ultrastrutural analysis on primary chromaffin cell membrane sheets, we show that PS exit occurs in domains at the frontier between the exocytotic granule membrane patch and the plasma membrane. In chromaffin cells expressing mutant phospholipid scramblase-1 (PLSCR-1) or in cells isolated from PLSCR-1 knock-out mouse, we found that outward transport of PS was abrogated during secretagogue-evoked exocytosis. Release of secretory products was normal in PLSCR-1-deficient cells but preventing PS egress severely inhibited compensatory endocytosis of secretory granule membrane components. This is the first evidence for an essential role of membrane lipid reorganization in the early endocytotic phases of regulated neuroendocrine secretion.

\section{Materials and Methods \\ DNA constructs, animals, and cell culture}

The N-terminally GFP-tagged mouse scramblase1 (PLSCR-1) was previously described (Zhao et al., 1998b). GFP-PLSCR-1 ${ }_{\text {D284A }}$ was generated by site-directed mutagenesis using the QuikChange mutagenesis kit (Agilent Technologies).

Chromaffin and PC12 cells were cultured as described previously (Gasman et al., 1997; Momboisse et al., 2009). Mammalian expression vectors $(3 \mu \mathrm{g})$ were introduced into chromaffin cells $\left(5 \times 10^{6}\right.$ cells, 24-well dishes) by Amaxa Nucleofactor Systems (Lonza) according to the manufacturer's instructions. Experiments were performed $48 \mathrm{~h}$ after transfection. PLSCR-1 $1^{+/-}$mice were purchased from CDTA (Cryopréservation, Distribution, Typage et Archivage animal), housed and raised at Chronobiotron UMS 3415. All mice were bred, handled, and maintained in agreement with European council directive 86/609/EEC and resulting French regulations. Mouse chromaffin cells were prepared from 8- to 12-week-old animals of either sex. The protocol was adapted from embryonic mouse cell culture method (Schonn et al., 2010). Adrenal glands were dissected and cleaned in filtered Locke's solution. The glands were gently opened with tweezers, and medulla was freed from fat and cortex under microscope before digestion in $1 \mathrm{ml}$ of papain solution $(25 \mathrm{U} / \mathrm{ml}$ papain in DMEM supplemented with $0.2 \mathrm{mg} / \mathrm{ml}$ L-cystein, $1 \mathrm{~mm} \mathrm{CaCl}_{2}, 0.5 \mathrm{~mm}$ EDTA, $0.067 \mathrm{~mm} \beta$-mercaptoethanol, equilibrated in $5 \% \mathrm{CO}_{2} / 95 \% \mathrm{O}_{2}$ ) for $30 \mathrm{~min}$ at $37^{\circ} \mathrm{C}$. The papain activity was inactivated for $5 \mathrm{~min}$ by addition of $500 \mu \mathrm{l}$ of DMEM supplemented with $10 \%$ heat-inactivated FCS, $2.5 \mathrm{mg} / \mathrm{ml}$ albumin, $2.5 \mathrm{mg} / \mathrm{ml}$ trypsin inhibitor (Sigma). The solution was carefully removed and replaced by $600 \mu \mathrm{l}$ of complete culture medium (DMEM, containing $0.2 \%$ primocin, Amaxa Systems, Lonza; and 1\% ITSX, Invitrogen). Medulla were washed twice with complete medium and gently triturated to get a cell suspension in $500 \mu \mathrm{l}$ of complete culture medium. Cells are seeded on collagen-coated coverslips and maintained at $37^{\circ} \mathrm{C}, 5 \% \mathrm{CO}_{2}$ for 24 or $48 \mathrm{~h}$ before experiments.

\section{RT-PCR}

Total RNA from bovine chromaffin cells culture was prepared using the GenElute Mammalian total RNA miniprep kit (Sigma). RNA $(2 \mu \mathrm{g})$ was transcribed into cDNA using oligo(dT) 12-18 and SuperScriptII Reverse Transcriptase (Invitrogen). A total of $1 \mu \mathrm{l}$ of the cDNA was used for amplification of the PLSCR-1 transcripts by PCR using TaqDNA polymerase (Sigma) and specific primers: forward, $5^{\prime}$-GATAATATGGGCCG AGAAGTCAT-3'; and reverse, 5' -GCCGAGCATCACAGCTTTCAT-3' . PCR reactions were run for 35 cycles and PCR product ( 390 base pairs) was analyzed on agarose gel. A control for absence of genomic contamination was performed in parallel without RT.

\section{Antibodies, immunofluorescence, confocal microscopy, and image analysis}

Monoclonal anti-TH antibodies were purchased from Millipore, and polyclonal anti-Syntaxin1 was from Santa Cruz Biotechnology. The polyclonal anti-dopamine- $\beta$-hydroxylase (DBH) and anti-PLSCR-1 4720 antibodies were as described previously (Sun et al., 2001; Ceridono et al., 2011). AlexaFluor-labeled secondary antibodies were obtained from Invitrogen. For immunocytochemistry, chromaffin cells grown on fibronectin-coated glass coverslips were fixed and immunostained as described previously (Kreft et al., 1999) and observed with a confocal microscope (SP5, Leica Microsystems) using a $63 \times$ objective (NA 1.40, Leica Microsystems).

For annexin-A5 binding, chromaffin cells were washed two times in Locke's solution (140 mM NaCl, $4.7 \mathrm{~mm} \mathrm{KCl}, 2.5 \mathrm{~mm} \mathrm{CaCl}_{2}, 1.2 \mathrm{~mm}$ $\mathrm{KH}_{2} \mathrm{PO}_{4}, 1.2 \mathrm{~mm} \mathrm{MgSO}$, $11 \mathrm{~mm}$ glucose, and $15 \mathrm{~mm}$ HEPES, $\mathrm{pH}$ 7.2) and then incubated for $10 \mathrm{~min}$ at $37^{\circ} \mathrm{C}$ in the presence of AlexaFluor-568conjugated annexin-A5 (Invitrogen) in Locke's solution (resting) or in elevated $\mathrm{K}^{+}$solution (Locke's solution containing $59 \mathrm{~mm} \mathrm{KCl}$ and $85 \mathrm{~mm} \mathrm{NaCl}$; stimulated). Cells were then fixed, and annexin-A5 staining was analyzed by confocal microscopy (SP5, Leica Microsystems). Images analyses were performed using ImageJ freeware (http://rsbweb.nih.gov/ij/).

\section{DBH internalization assays and Euclidean distance map analysis}

Anti-DBH antibody internalization assay with bovine chromaffin cells was performed as described previously (Ceridono et al., 2011). Briefly, chromaffin cells were washed twice in Locke's solution and then incubated for $10 \mathrm{~min}$ at $37^{\circ} \mathrm{C}$ in Locke's solution (resting) or stimulated with elevated $\mathrm{K}^{+}$solution. Cells were then placed on ice, washed once in Locke's solution, and incubated for $30 \mathrm{~min}$ at $4^{\circ} \mathrm{C}$ in the presence of polyclonal anti-DBH antibodies (1/1000). Cells were then washed rapidly with Locke's solution and fixed (stimulated/exocytosis) or further incubated at $37^{\circ} \mathrm{C}$ for $15 \mathrm{~min}$ (chase/endocytosis) before fixation. Cells were then processed for immunofluorescence. For the first time, this DBH internalization assay was adapted for chromaffin cells cultured from mice: cells were rapidly washed and maintained under resting conditions or stimulated for $10 \mathrm{~min}$ at $37^{\circ} \mathrm{C}$ in Locke $\mathrm{K}^{+}$solution in the presence of anti-DBH antibodies. Cells were then washed with Locke's solution and fixed (stimulated/exocytosis) or further incubated at $37^{\circ} \mathrm{C}$ for $15 \mathrm{~min}$ (chase/ endocytosis) before fixation and immunofluorescence experiments.

As previously described, the distribution of $\mathrm{DBH}$-containing granules was analyzed by Euclidean distance map (Ceridono et al., 2011). Briefly, confocal pictures were segmented using ImageJ to isolate DBH-positive vesicles and to generate corresponding region of interest. Cell periphery was outlined using plasma membrane marker staining and cell area transformed into Euclidean distance map where each pixel has a value of the minimum Euclidean distance from the cell periphery. Relative vesicles position was determined according to mean gray intensity measured in each region of interest once transposed on Euclidean distance map. Vesicles were considered internalized when mean gray value was $>20$ for bovine chromaffin cells and 10 for mice chromaffin cells. For more details, see Ceridono et al. (2011) (their Materials and Methods and supplemental Fig. 1).

\section{Amperometry}

Bovine chromaffin cells were transfected with plasmid coding for either EGFP alone, GFP-tagged PLSCR-1, or GFP-tagged PLSCR-1 $1_{\text {D284A }}$. At $48 \mathrm{~h}$ later, cells were washed with Locke's solution and processed for catecholamine release measurements by amperometry. Carbon-fiber electrode of 5 $\mu \mathrm{m}$ diameter (ALA Scientific) was held at a potential of $+650 \mathrm{mV}$ compared with the reference electrode $(\mathrm{Ag} / \mathrm{AgCl})$ and approached closely to the transfected cells. Catecholamine's secretion was induced by $10 \mathrm{~s}$ pressure ejection of $100 \mathrm{mM} \mathrm{K}^{+}$solution from a micropipette positioned at $\sim 10 \mu \mathrm{m}$ from the cell and recorded during $100 \mathrm{~s}$. Amperometric recordings were performed with an AMU130 (Radiometer Analytical) amplifier, sampled at $5 \mathrm{kHz}$, and digitally low-passed filtered at $1 \mathrm{kHz}$. Analysis of amperometric recordings was done as previously described (Mosharov and Sulzer, 2005) with a macro (obtained from Dr. R. Borges laboratory; http://webpages.ull.es/ users/rborges/) written for Igor software (Wavemetrics), allowing automatic spike detection and extraction of spike parameters. The number of 
amperometric spikes was counted as the total number of spikes with an amplitude $>5 \mathrm{pA}$ within $100 \mathrm{~s}$.

\section{GH release from $\mathrm{PC1} 2$ cells}

PC12 cells were transfected using Lipofectamine 2000 (Invitrogen) according to the manufacturer's instructions (24-well dishes, $1 \times 10^{5}$ cells, $0.4 \mu \mathrm{g}$ of each plasmid /well). GH release experiments were performed $48 \mathrm{~h}$ after transfection. PC12 cells were washed four times with Locke's solution and then incubated for $10 \mathrm{~min}$ in Locke's solution (basal release) or stimulated with an elevated $\mathrm{K}^{+}$solution. The supernatant was collected and the cells were harvested by scraping in PBS. The amounts of $\mathrm{GH}$ secreted into the medium and retained in the cells were measured using an ELISA (Roche Diagnostics). GH secretion is expressed as a percentage of total GH present in the cells before stimulation.

\section{Lipid analysis by chromatography and mass spectrometry}

Lipids from wild-type and knock-out mice adrenal medulla were extracted as previously described (Bligh and Dyer, 1959). Lipid samples were then suspended in $200 \mu \mathrm{l}$ of a mixture containing methanol and dichloromethane $(1: 2 \mathrm{v} / \mathrm{v})$ and analyzed on an ultra performance liquid chromatography coupled to tandem mass spectrometry (UPLC-MS/MS) at MS/MS mode.

For cholesterol, the analyses were performed on a Waters Quattro Premier XE (Waters) equipped with an atmospheric pressure photon ionization source and coupled to an Acquity UPLC system (Waters). Chromatographic separation was achieved using an Acquity UPLC BEH $\mathrm{C}_{8}$ column $(100 \times 2.1 \mathrm{~mm}, 1.7 \mu \mathrm{m}$; Waters $)$, coupled to an Acquity UPLC BEH C $\mathrm{C}_{8}$ precolumn $(2.1 \times 5 \mathrm{~mm}, 1.7 \mu \mathrm{m}$; Waters $)$. The mobile phases selected were $75 \%$ methanol/in water with $0.01 \%$ formic acid (solvent A) and $99.99 \%$ isopropanol with $0.01 \%$ formic acid (solvent B). A linear gradient was applied for a total run time of $48 \mathrm{~min}$. The MRM transitions used for cholesterol were as follow: $369.5>161$. Data acquisition and analysis were performed with the MassLynx software (version 5.1). For the phospholipids (PS and PE), the analyses were performed on a Waters Quattro Premier XE (Waters) equipped with an electrospray ionization. Chromatographic separation was achieved as described above for cholesterol analysis. The two mobile phases were water with $1 \%$ $1 \mathrm{M} \mathrm{NH}_{4} \mathrm{Ac}, 0.1 \%$ acetic acid (buffer A), and acetonitrile: isopropanol (7:3,UPLC grade Sigma) containing $1 \% 1 \mathrm{M} \mathrm{NH}_{4} \mathrm{Ac}, 0.1 \%$ acetic acid (buffer B). A linear gradient was applied for a total run time of $25 \mathrm{~min}$. The mass spectra were acquired using the selected ion recording MS mode to determine parent mass transition. The cone voltage was set to $25 \mathrm{~V}$. Standard PS and PE have been analyzed by LC-MS as previously described (Houjou et al., 2005; Bang et al., 2007).

\section{Transferrin and dextran uptake in chromaffin cells}

Mouse chromaffin cells were serum-starved for $1 \mathrm{~h}$ at $37^{\circ} \mathrm{C}$ and subsequently incubated for $30 \mathrm{~min}$ at $37^{\circ} \mathrm{C}$ in DMEM containing $100 \mu \mathrm{g} / \mathrm{ml}$ AlexaFluor-555-conjugated transferrin (Invitrogen). After serum starvation, fluid-phase uptake was monitored by adding $3 \mathrm{kDa}$ TRITCconjugated dextran (Sigma) in DMEM containing 10\% FCS. Cells were then washed, fixed, and processed for immunofluorescence. Fluorescence intensity was measured and normalized to cell surface area determined by phase-contrast image.

\section{Scanning electron microscopy of plasma membrane sheets and mathematical analysis of clusters distribution}

Cytoplasmic face-up membrane sheets were prepared and processed as previously described (Umbrecht-Jenck et al., 2010). Briefly, carboncoated Formvar films nickel electron microscopy grids were inverted onto resting or $\mathrm{K}^{+}$-stimulated chromaffin cells incubated with $\mathrm{DBH}$ antibodies and streptavidin-conjugated annexin-A5. Cells were fixed in 2\% paraformaldehyde in PBS for 10 min. After blocking in PBS with $1 \%$ BSA and $1 \%$ acetylated BSA, the immunolabelings were performed and revealed with $10 \mathrm{~nm}$ gold particle-conjugated secondary antibodies and 6 $\mathrm{nm}$ particle-conjugated biotin (Aurion). To prepare membrane sheets, a pressure was applied to the grids for $20 \mathrm{~s}$ and the grids were lifted, leaving fragments of the upper cell surface adherent to the grid. These membrane portions were fixed in $2 \%$ glutaraldehyde in PBS, postfixed with $1 \%$ OsO4, dehydrated in a graded ethanol series, treated with hexamethyldisilazane (Sigma), air-dried, and examined using a Hitachi 7500 transmission electron microscope. In the absence of stimulation (resting conditions), no gold particles were detected.

For clustering analysis, gold particles were picked up using ImageJ and particles coordinates analyzed using hierarchical clustering and dendograms developed under Matlab (Espinoza et al., 2012). Briefly, the biological data consist of $M>0$ particles, which will be modeled as points in the Cartesian plane: $p_{j}=\left(x_{j} y_{j}\right), 1 \leq j \leq M$. Clustering is defined in terms of two functions: the distance function and the linkage function. The distance function computes the distance between points and the linkage function computes the distance between clusters. Clustering results often vary based on the choice of these functions. The distance between points is defined as follows:

$$
\Phi_{j, k}=\left\|p_{j}-p_{k}\right\|=\sqrt{\left(x_{j}-y_{k}\right)^{2}+\left(y_{j}-y_{k}\right)^{2}},
$$

which is the Euclidean distance. The clusters depend on the choice of a clustering distance $\mathrm{d} \geq 0$. Then, if two points satisfy $\phi_{j, k} \leq d$, they are in the same cluster. Next, let $A$ and $B$ be two clusters containing points $a_{\alpha}$ and $b_{\beta}$, then the distance between two clusters is defined as follows:

$$
\phi(A, B)=\min _{\alpha \beta} \phi\left(a_{\alpha}, b_{\beta}\right)
$$

which is known as single-linkage merge criterion (Espinoza et al., 2012). If $\phi(A, B) \leq d$, then $A$ and $B$ are combined into a single cluster. Average size of secretory granules in chromaffin cells ranges from 200 to $350 \mathrm{~nm}$. Therefore, a granule membrane that has flattened into the plasma membrane after exocytosis is expected to display an average diameter ranging from 400 to 700 $\mathrm{nm}$ (Ceridono et al., 2011). Thus, for DBH cluster analysis, we fixed $d$ at 400 $\mathrm{nm}$ and considered clusters with a minimum of 4 particles per cluster. By doing so, the maximum distance between single DBH particles in a cluster will not exceed $700 \mathrm{~nm}$. For annexin-A5 clusters, we used the intrinsic clustering distance $(\mathrm{dI})$, which characterized the distance between points and the nanoscale structure of any clustering in the data (Espinoza et al., 2012). dI corresponds to the distances that produce the maximum number of clusters in the biological data, eliminating the need to choose a distance. For annexin-A5 clusters, $\mathrm{dI}$ has been calculated for each image and ranges from 32 to $160 \mathrm{~nm}$. Distance distribution was calculated and compared with distances obtained from 10 iterations of randomly distributed centroids corresponding to the number of $\mathrm{DBH}$ and annexin-A5 clusters found in each picture. When multiple annexin-A5 and DBH centroids were present, only the shortest distance between centroids was kept for analysis.

\section{Transmission electron microscopy of wild-type and PLSCR-1 ${ }^{-1-}$ chromaffin cells in situ}

Wild-type $(n=2)$ and PLSCR-1 ${ }^{-/-}(n=2)$ mice were anesthetized with a mixture of ketamine $(100 \mathrm{mg} / \mathrm{kg})$ and xylazine $(5 \mathrm{mg} / \mathrm{kg})$ and transcardiacally perfused with $0.1 \mathrm{~m}$ phosphate buffer, $\mathrm{pH} 7.3$, containing $2 \%$ paraformaldehyde and $2.5 \%$ glutaraldehyde. The 2-mm-thick slices were cut from the adrenal glands and postfixed in $1 \%$ glutaraldehyde in phosphate buffer overnight at $4^{\circ} \mathrm{C}$. The slices were then immersed for $1 \mathrm{~h} \mathrm{in}$ $\mathrm{OsO}_{4} 0.5 \%$ in phosphate buffer. The $1 \mathrm{~mm}^{3}$ blocks were cut in the adrenal medulla, dehydrated, and processed classically for embedding in Araldite and ultramicrotomy. Ultrathin sections were counterstained with uranyl acetate and examined with a Hitachi 7500 transmission electron microscope. Secretory granules were counted in 60 chromaffin cells with a visible nucleus randomly selected in ultrathin sections from several blocks ( 1 section/block) from each mouse.

\section{Data analysis}

In all the figures, data are given as the mean \pm SEM; $n$ represents either the number of experiments, cells, or images analyzed from at least three independent experiments performed on different cell cultures. Data were analyzed with Minitab statistical software. Statistical significance has been established using ANOVA test, and data were considered significantly different when $p<0.05$. Gaussian distribution and variance equality of the data were verified. 
A
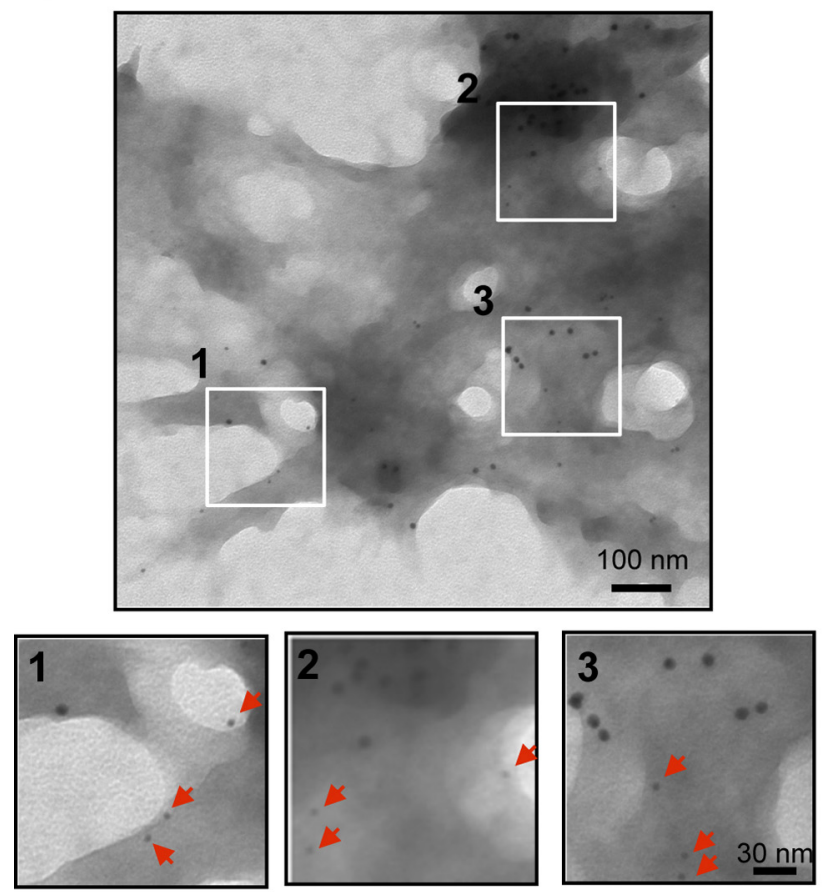

C

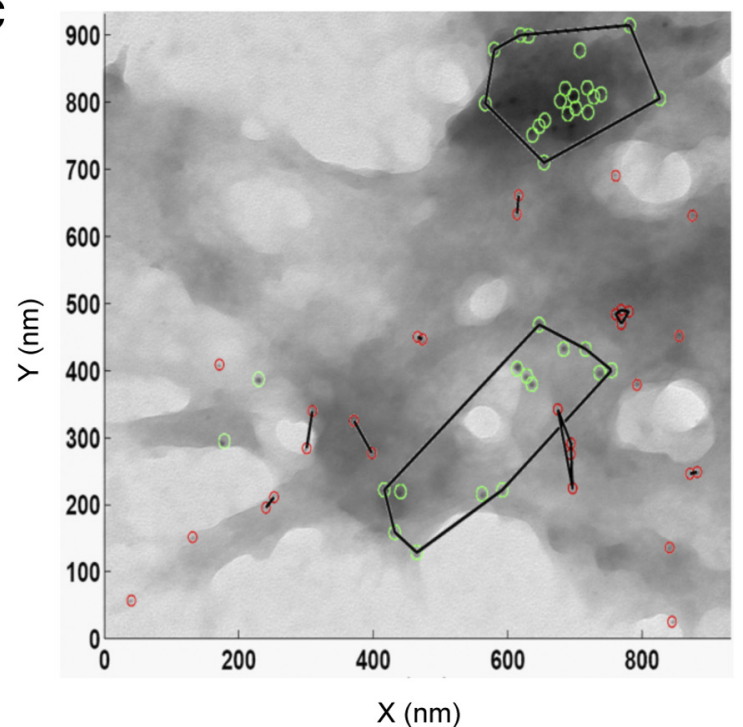

B

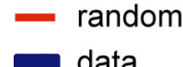

data

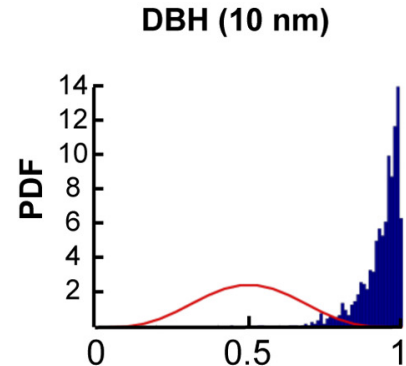

Annexin-A5 (6 nm)

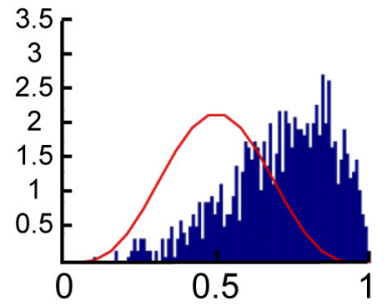

The Hopkins statistic

D

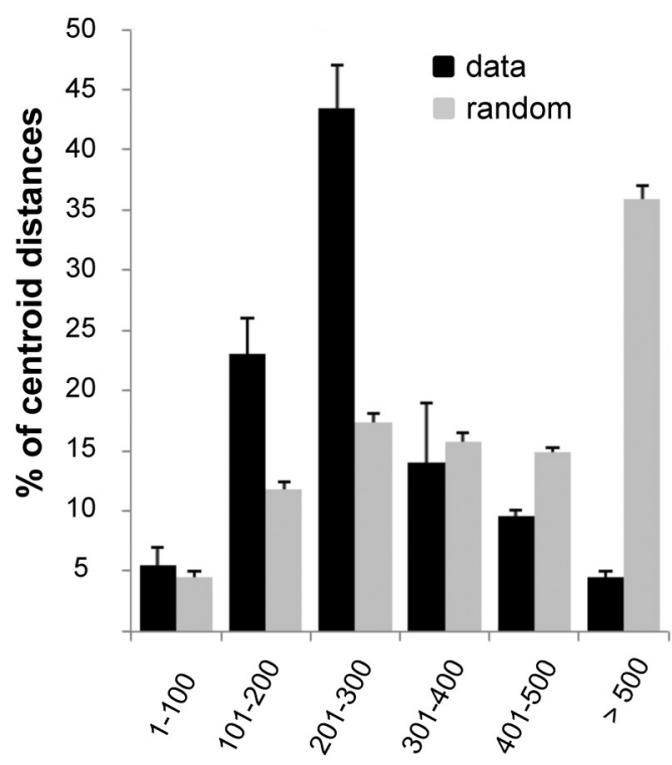

Distance intervals (nm)

Figure 1. Clusters of PS surround DBH at exocytic sites. $A$, Plasma membrane sheets were prepared from bovine chromaffin cells stimulated by 59 mm $K^{+}$for 10 min. To label DBH and PS exposed at the surface of cells undergoing exocytosis, anti-DBH antibody and annexin-A5 coupled to biotin were added during stimulation. Membrane sheets were labeled with anti-rabbit antibodies coupled to $10 \mathrm{~nm}$ gold particles to detect DBH antibodies revealing exocytotic sites and streptavidin coupled to $6 \mathrm{~nm}$ gold particles to label annexin-A5 revealing PS. Then membrane sheets were performed. Close-up pictures are shown, and red arrows point to $6 \mathrm{~nm}$ gold particles. $\boldsymbol{B}$, Hopkins statistical analysis of DBH (10 nm) and annexin-A5/PS ( $6 \mathrm{~nm}$ ) distribution compared with a random distribution (red line). $\boldsymbol{C}$, Hierarchical clustering analysis of annexin-A5/PS and DBH clusters. Green circles represent $10 \mathrm{~nm}$ gold particles (DBH), and red circles represent $6 \mathrm{~nm}$ gold particles (annexin-A5/PS). DBH and annexin-A5 clusters are delineated by convex hulls ( $\mathrm{d}=400 \mathrm{~nm}$ for DBH and $56 \mathrm{~nm}$ for annexin-A5 clusters). $D$, Distribution of distances measured between centroids of DBH and annexin-A5 clusters as determined by hierarchical clustering. Clusters of annexin-A5 found inside anti-DBH clusters were considered colocalized and excluded from the graph. Shortest distances between DBH and annexin-A5 centroid clusters from experimental data were measured and compared with distances between centroids randomly positioned in pictures. Distribution of distances from experimental data are shifted toward shortest distances compared with random calculation with $72 \%$ of centroid distances $<300 \mathrm{~nm}$ compared with $33 \%$ for random data. This indicates that a large proportion of annexin-A5/PS clusters are in the close vicinity of DBH clusters ( $n=32$ cells).

\section{Results}

Hot spots of cell surface PS appear at the periphery of exocytic sites in chromaffin cells

We previously reported that secretagogue-evoked stimulation of chromaffin cells triggers the appearance of PS at the cell surface, presumably at the granule fusion sites as estimated at the confocal microscopy resolution (Ceridono et al., 2011). To specify the localization of the PS exit sites versus granule membranes transiently inserted into the plasma membrane, we prepared plasma membrane sheets from bovine chromaffin cells stimulated with a depolarizing concentration of $\mathrm{K}^{+}$in the presence of anti-DBH antibodies to reveal exocytotic granule 
A

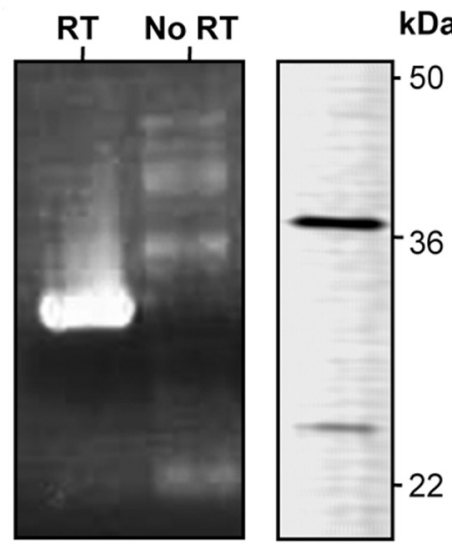

B

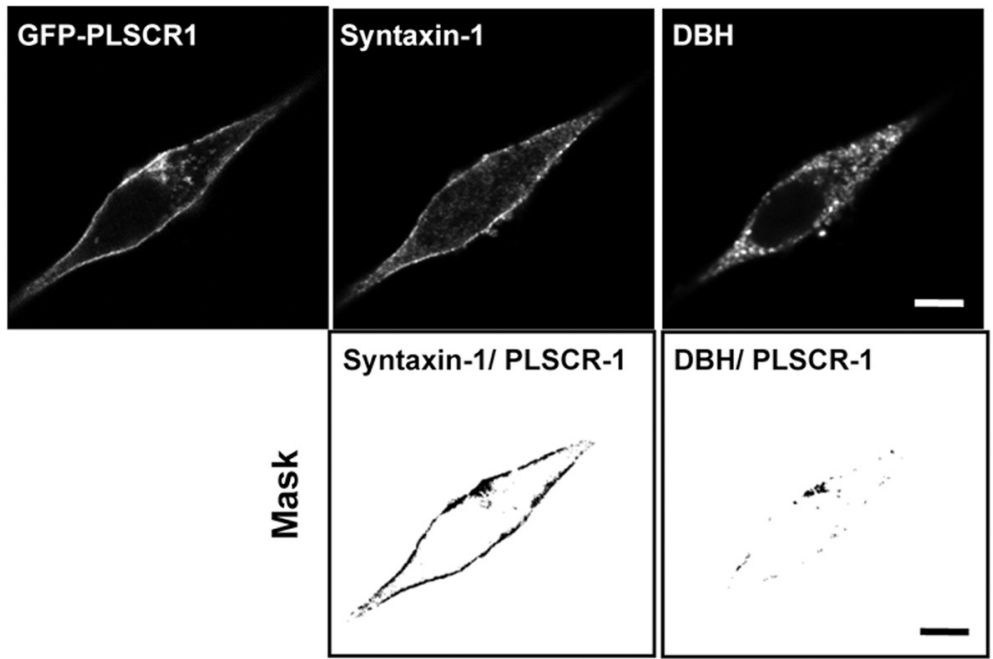

Figure 2. $\quad A, P L S C R-1$ is expressed in chromaffin tissues. Detection of PLSCR-1 mRNA by RT-PCR (left) and PLSCR-1 protein by Western blot (right) in bovine and mouse chromaffin cells, respectively. A control without RT is shown (left panel, lane no RT). $\boldsymbol{B}$, Expressed GFP-tagged PLSCR-1 is mainly localized at the plasma membrane. Bovine chromaffin cells were transfected with GFP-PLSCR-1 and labeled for syntaxin-1 and DBH. Masks of colocalized GFP-PLSCR-1/syntaxin-1 or GFP-PLSCR-1/DBH pixels are shown (bottom). Scale bars, $5 \mu \mathrm{m}$.
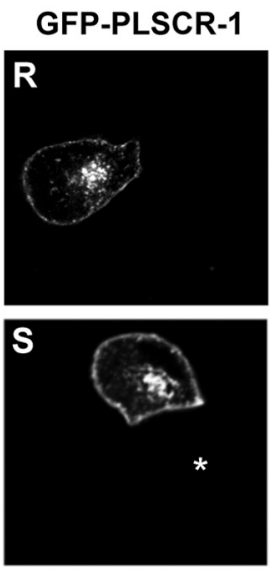

\section{Annexin-A5}
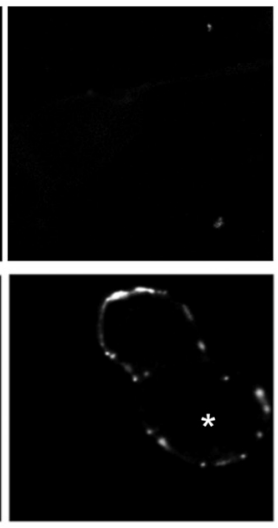
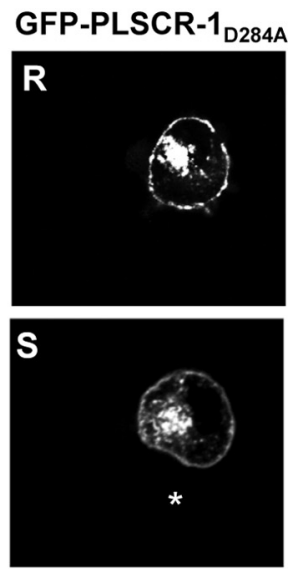

Annexin-A5
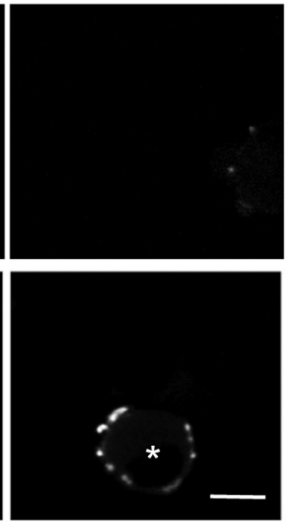

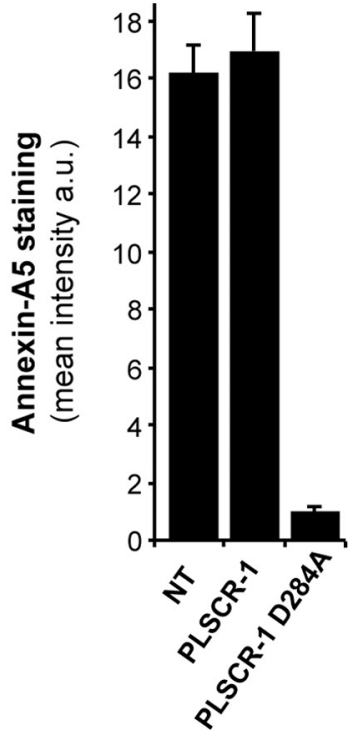

Figure 3. Inactive PLSCR-1 prevents PS exit during secretagogue-evoked exocytosis. Confocal images of bovine chromaffin cells expressing GFP-tagged PLSCR-1 or GFP-tagged PLSCR-1 D284A $^{\text {. }}$ Cells were maintained under resting conditions (R) or stimulated for 10 min with $59 \mathrm{~mm} \mathrm{~K}^{+}(\mathrm{S})$ in the presence of fluorescent annexin-A5 to reveal PS at the cell surface. Scale bar, $5 \mu \mathrm{m}$. *Nontransfected cells (NT). Mean annexin-A5 fluorescence intensity is represented by the graph on the right ( $n=25$ cells). Expression of EGFP alone did not modify the level of annexin-A5 staining (data not shown).

membrane and biotinylated annexin-A5 to detect external PS. Membranes were then incubated with anti-rabbit antibodies coupled to $10 \mathrm{~nm}$ gold to reveal $\mathrm{DBH} /$ anti-DBH complexes and streptavidin coupled to $6 \mathrm{~nm}$ gold to reveal annexinA5/PS complex. Ultrastructural images obtained by transmission electron microscopy showed that annexin-A5 tends to localize close to the DBH particles (Fig. 1A). The Hopkins statistic test (Zhang et al., 2006) was used to establish whether annexin-A5/PS was clustered or randomly distributed. As illustrated in Figure $1 B$, both DBH and annexin-A5 distribution were significantly shifted to the right of the curve expected for a random distribution, indicating that both staining sites were organized into clusters.
The distribution of annexin-A5/PS relative to DBH clusters was examined using a mathematical analysis of the gold particle distribution based on hierarchical clustering approach (for details, see Material and Methods) (Espinoza et al., 2012). Fig. $1 C$ shows convex hulls of a representative electron micrograph with $\mathrm{DBH}$ and annexin-A5 clusters. Most of the annexin-A5 clusters $(89.4 \pm 6.1 \%)$ as well as the single annexin-A5 particles (85.2 \pm $6.4 \%$ ) localized outside the DBH clusters, indicating that PS outward translocation did not occur within the exocytotic granule membrane itself. Figure $1 D$ shows the distribution of distances between centroids of the DBH and annexin-A5 clusters. To avoid possible bias, we compared experimental data (Fig. 1D, data) with distances obtained mathematically from the same number 
of clusters but randomly positioned in pictures (Fig. 1D, random). Experimental data indicated that the majority of PS cluster centroids (72\%) were found at a distance below $300 \mathrm{~nm}$ of the DBH cluster centroids, as opposed to only $33 \%$ with random data (Fig. 1D). The average distance separating centroids was also highly increased with random data $(431 \pm 6 \mathrm{~nm}$ compared with $219 \pm 14 \mathrm{~nm}$ with experimental data). These differences between random calculation and experimental data are consistent with the idea that PS translocation occurs at specific sites in the vicinity of the granule membrane patch merged with the plasma membrane.

\section{PLSCR-1 protein is linked to the} secretagogue-induced translocation of PS at the chromaffin cell surface In theory, the phospholipid asymmetry at the plasma membrane can be abolished by phospholipid scramblases (PLSCR). The PLSCR proteins were originally identified and cloned based on their scramblase activity measured in a reconstituted proteoliposome system (Basse et al., 1996). PLSCR-1 has been implicated as one protein that might participate in the transbilayer redistribution of phospholipids (Sims and Wiedmer, 2001; Devaux et al., 2006). Thus, we decided to examine whether PLSCR-1 might be expressed in chromaffin tissues and whether PLSCR-1 might be involved in PS asymmetry disruption. By RT-PCR and Western blot experiments, we detected the PLSCR-1 messenger in cultured bovine chromaffin cells and the PLSCR-1 protein in mouse adrenal glands tissue at the expected molecular weight of $36 \mathrm{kDa}$ (Fig. 2A).

Because we could not detect endogenous PLSCR-1 by immunofluorescence with the antibodies currently available, we examined the distribution of exogenously expressed GFP-tagged PLSCR-1 in chromaffin cells labeled with plasma membrane (syntaxin-1) or secretory granules (DBH) markers (Fig. 2B). GFP-PLSCR-1 was mostly detected in cell periphery and to lesser extent in endomembranes. PLSCR-1 was largely found colocalized with syntaxin-1 but not with DBH, indicating that PLSCR-1 was most likely associated with the plasma membrane and not with secretory granules.

To assess whether PLSCR-1 is functionally implicated in PS outward movement during exocytosis, we transfected bovine chromaffin cells with cDNAs encoding either wild-type PLSCR-1 or a calcium-insensitive PLSCR-1 $1_{\mathrm{D} 284 \mathrm{~A}}$ mutant unable to trigger PS redistribution (Zhou et al., 1998a). Both constructs were fused to GFP. Cells were stimulated with a depolarizing $\mathrm{K}^{+}$concentration, and the appearance of PS at the cell surface was detected with fluorescent annexin-A5 added to the cell incubation solution. No annexin-A5 binding was observed in nonstimulated cells, confirming the absence of PS at the outer leaflet of the plasma membrane in resting conditions (Fig. 3). Annexin-A5 decorated $\mathrm{K}^{+}$-stimulated PLSCR-1-transfected cells as efficiently as nontransfected cells, indicating that PS was translocated in response to secretagogue-evoked stimulation. In contrast,
annexin-A5 staining was drastically inhibited in cells expressing the $\mathrm{Ca}^{2+}$-insensitive PLSCR-1 $1_{\mathrm{D} 284 \mathrm{~A}}$ mutant (Fig. 3). Similar results were obtained when cells were stimulated with $10 \mu \mathrm{M}$ nicotine (data not shown). Thus, PLSCR-1 activity contributes to the cell surface exposure of PS that occurs during the exocytotic process.

\section{$\mathrm{Ca}^{2+}$-dependent PLSCR-1 activity is not required for} exocytosis but for secretory granule membrane endocytosis To investigate the potential involvement of PLSCR-1 in exocytosis, we measured catecholamine release in bovine chromaffin cells expressing PLSCR-1 or PLSCR-1 $1_{\mathrm{D} 284 \mathrm{~A}}$ using carbon fiber amperometry to monitor real-time single granule exocytosis (Mosharov and Sulzer, 2005). Figure $4 A$ shows representative amperometric traces recorded from chromaffin cells expressing EGFP (control), PLSCR-1, or PLSCR-1 ${ }_{\mathrm{D} 284 \mathrm{~A}}$ mutant. Amperometric spikes representing the release of catecholamines from one single granule were measured over a period of $100 \mathrm{~s}$. We found that the number of amperometric events was similar in cells expressing EGFP, PLSCR-1, and PLSCR-1 $1_{\mathrm{D} 284 \mathrm{~A}}$ mutant (Fig. $4 B$ ), indicating that altering PLSCR-1 activity did not affect the number of exocytotic granule fusion events. To further confirm that PLSCR-1 activity was not linked to exocytosis and protein secretion, we measured exocytotic release of growth hormone $(\mathrm{GH})$ from PC12 cells expressing PLSCR-1 proteins. As illustrated in Figure $4 C$, neither PLSCR-1 nor PLSCR-1 $1_{\text {D284A }}$ mutant affected the amount of $\mathrm{GH}$ secreted in response to high $\mathrm{K}^{+}$evoked stimulation. 
A

GFP

DBH

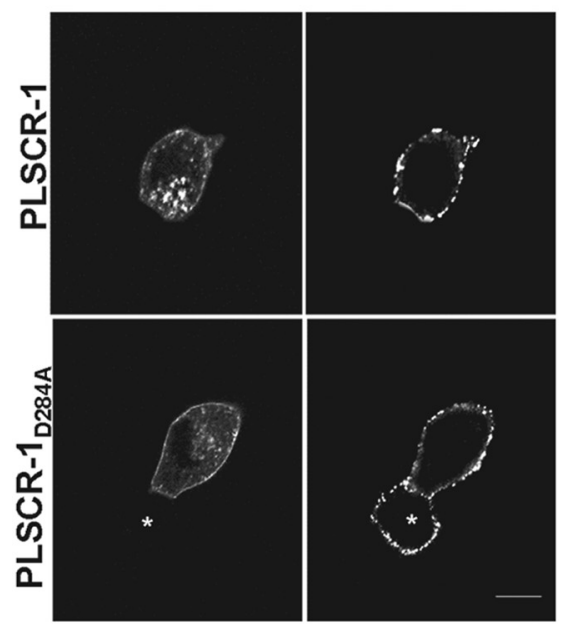

Stimulated

C

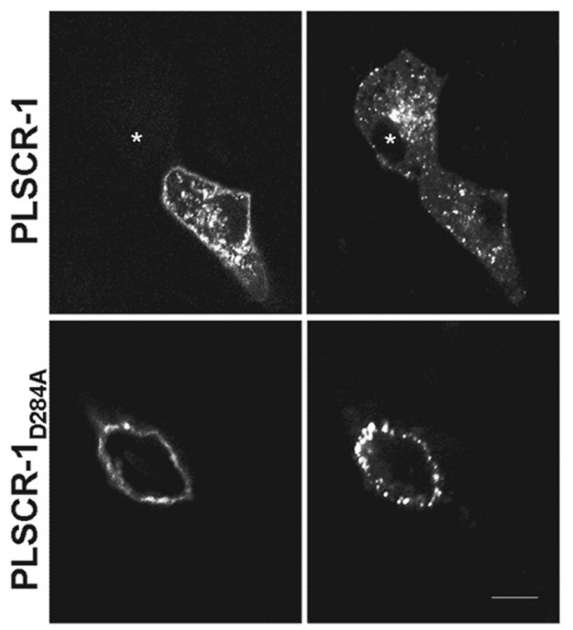

15 min chase
B

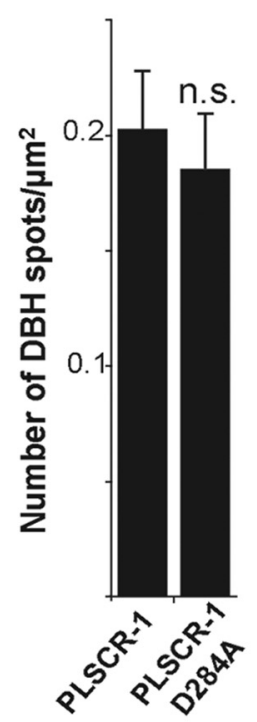

D

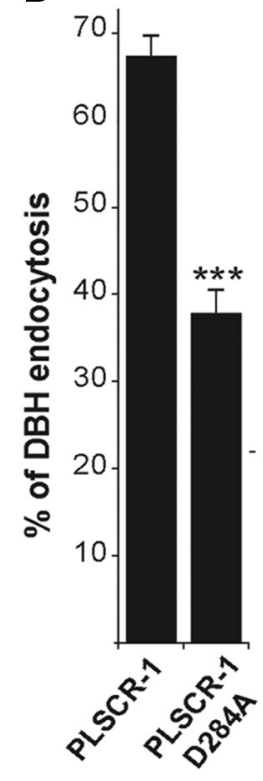

Figure 5. Inactive PLSCR-1 inhibits compensatory endocytosis. Bovine chromaffin cells expressing PLSCR-1 or PLSCR-1 $1_{\text {D284A }}$ fused to GFP were stimulated for 10 min with $59 \mathrm{~mm} \mathrm{~K}^{+}$and then incubated for 30 min at $4^{\circ} \mathrm{C}$ in the presence of anti-DBH antibodies in the external medium. Cells were then fixed $\left(\boldsymbol{A}\right.$, Stimulated) or incubated for an additional 15 min in $37^{\circ} \mathrm{C}$ Locke's solution to allowDBH endocytosis and then fixed ( $C, 15 \mathrm{~min}$ chase). Anti-DBH antibodies were revealed with secondary antibodies coupled to Alexa-555. Representative pictures are shown. *Nontransfected cells. Scale bars, $5 \mu \mathrm{m}$. B, Quantitative analysis of DBH-labeled patches density ( $n=25$ cells). $\boldsymbol{D}$, Analysis of the internalization of DBH-positive vesicles by Euclidean distance map. After 15 min chase, DBH uptake was reduced by $50 \%$ in cells expressing the PLSCR-1 ${ }_{\text {D284A }}$ mutant. ${ }^{* * *} p<0.001$, compared with cells expressing PLSCR-1 ( $n=25$ cells). n.s., Not significant.

To probe the function of PLSCR-1-induced translocation of PS in secretory granule endocytosis, we took advantage of the anti-DBH antibody internalization assay we have recently described (Ceridono et al., 2011). Because granule membrane fusion with the plasma membrane triggers transient accessibility of $\mathrm{DBH}$ (an intraluminal membrane-associated granule protein) to the extracellular space, exocytotic spots on the chromaffin cell surface can be visualized by incubating living cells with anti-DBH

antibodies. Compensatory endocytosis is then measured by following the internalization of the anti-DBH antibodies bound to the cell surface after exocytosis (for details see Material and Methods) (Ceridono et al., 2011).

We found that amounts of cell surface DBH patches that appeared upon high-potassium stimulation (Fig. 5A,B) or nicotinic stimulation (data not shown) were similar in chromaffin cells expressing PLSCR-1 or PLSCR-1 ${ }_{\mathrm{D} 284 \mathrm{~A}}$ mutant, confirming that PLSCR-1 does not play a role in exocytosis. However, when chase experiments were performed, DBH internalization was reduced by $\sim 50 \%$ in PLSCR-1 $1_{\mathrm{D} 284 \mathrm{~A}}$ compared with PLSCR-1expressing cells: after $15 \mathrm{~min}, 37.9 \pm 2.9 \%$ of the total $\mathrm{DBH}$ was internalized in PLSCR-1 $1_{\mathrm{D} 284 \mathrm{~A}}$ expressing cells versus $67.4 \pm 3.0 \%$ in PLSCR-1-expressing cells (Fig. 5C,D).

Together, these results suggest that calcium-induced PLSCR-1 activity and the resulting PS redistribution at the plasma membrane are not required for granule fusion and exocytosis but are critical for secretory granule membrane retrieval.

\section{Outward translocation of PS and secretory granule compensatory endocytosis are abolished in chromaffin cells from PLSCR-1 knock-out mouse}

To get further insight into the function of PLSCR-1 in chromaffin cell secretion and to circumvent possible drawbacks resulting from protein overexpression, we adapted the $\mathrm{DBH}$-internalization assay to cultured mouse chromaffin cells obtained from PLSCR-1 knockout mice (PLSCR-1 ${ }^{-1-}$ ). Immunoblot analysis confirmed the absence of PLSCR-1 expression in adrenal medulla tissue from PLSCR$1^{-1-}$ mouse (Fig. 6A). Ultrastructural images revealed that the number and the distribution of large dense-core secretory granules remained unchanged in PLSCR-1-deficient chromaffin cells (Fig. $6 B, C)$.

We first examined PS exit upon $\mathrm{K}^{+}$-evoked chromaffin cell stimulation using annexin-A5 in extracellular medium. As shown in Figure $6 D, E$, annexin-A5 binding was dramatically reduced in PLSCR- $1^{-/-}$compared with WT (PLSCR-1 ${ }^{+/+}$) chromaffin cells, indicating that PS exit does not occur in the absence of PLSCR-1. To rule out a possible effect of PLSCR-1 knock-out on the global lipid metabolism, we measured the total level of some selected lipids, such as PS and PE, known to be regulated by PLSCR-1 or cholesterol important for establishing exoendocytotic sites (Chasserot-Golaz et al., 2005; Wang et al., 2010). Therefore, lipidomic analysis on lipid extracts obtained from WT (PLSCR-1 ${ }^{+/+}$) and PLSCR-1 knock-out mice (PLSCR-1 ${ }^{-/-}$) adrenal medulla was performed using sensitive liquid chromatography-tandem mass spectrometry (Houjou et al., 2005; Bang et al., 2007). As shown in Figure 6F, the total amount of PS, PE, and cholesterol remains unchanged in PLSCR-1 knock-out mice adrenal medulla compared with wild-type mice, indicating that the reduction in PS delivery to the cell surface observed in secretagogue-stimulated PLSCR-1 ${ }^{-1-}$ cells does not result from a reduction in total PS levels in these cells.

Next, we analyzed secretory granule exocytosis and endocytosis using the anti-DBH antibody internalization assay. Similarly to bovine chromaffin cells expressing the inactive PLSCR-1 mutant (Fig. 5), high $\mathrm{K}^{+}$-stimulated PLSCR-1 ${ }^{-/-}$cells exhibited cell surface $\mathrm{DBH}$ patches to a similar extent than wild-type cells (Fig. $7 A, B$ ), indicating that exocytosis is not impaired in the absence of PLSCR-1 activity. However, DBH chase experiments showed that compensatory endocytosis was drastically inhibited because after 15 min only $19.7 \pm 3.7 \%$ of the total $\mathrm{DBH}$ was internalized in 
A

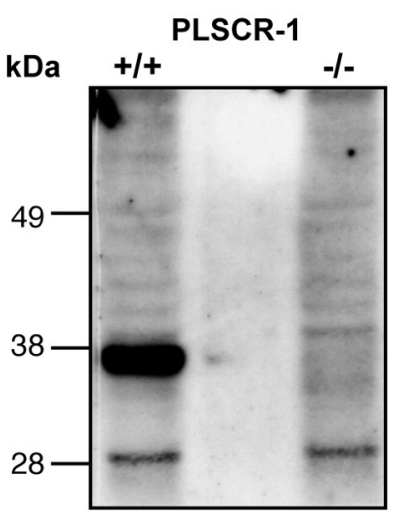

B

PLSCR-1+1+

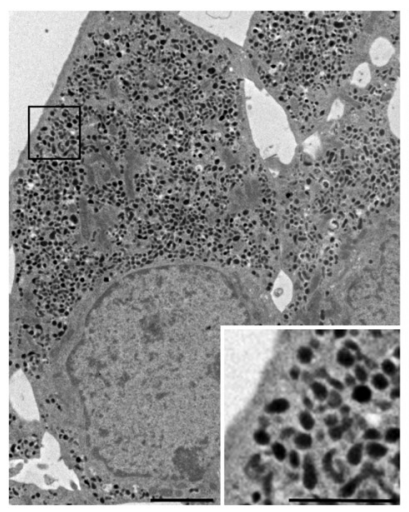

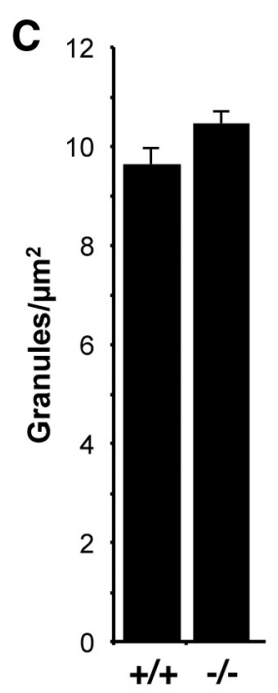

D

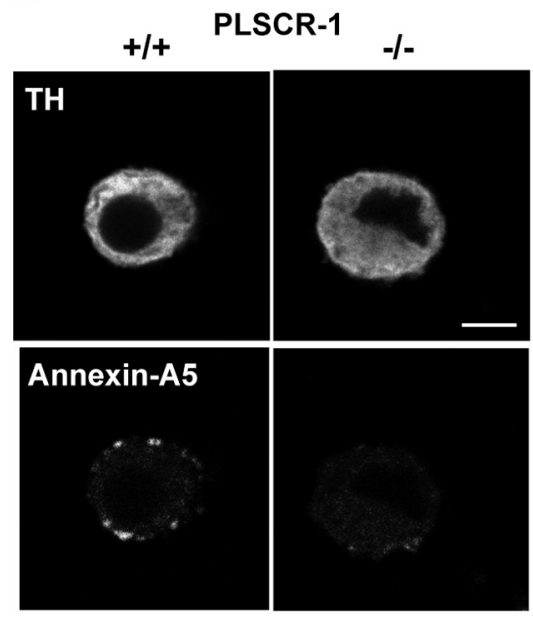

E

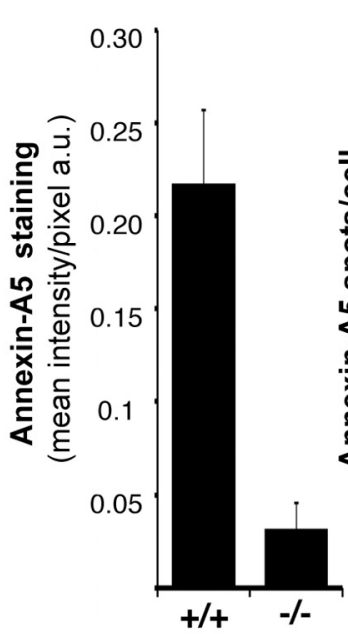

PLSCR-1-/-

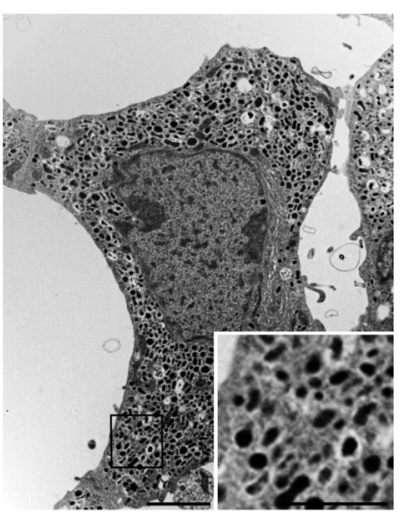

F 
A

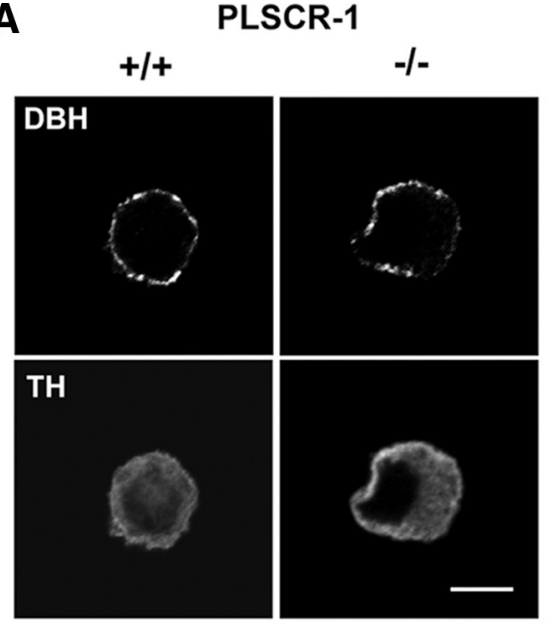

Stimulated

C
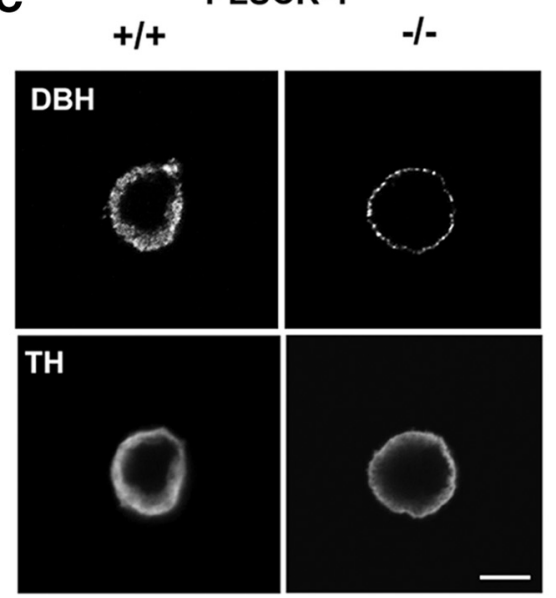

15 min chase
B

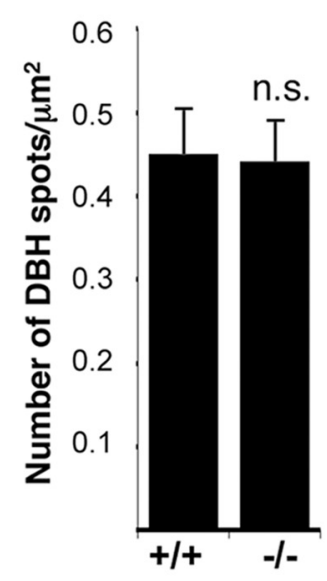

D

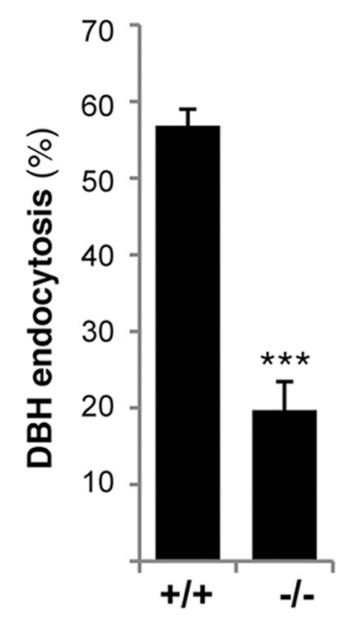

Figure 7. Compensatory endocytosis is impaired in PLSCR-1 ${ }^{-1-}$ mouse chromaffin cells. $A$, Quantification of exocytosis sites using anti-DBH antibodies. Cells were stimulated for $10 \mathrm{~min}$ with $59 \mathrm{~mm} \mathrm{~K}^{+}$in the presence of anti-DBH antibodies, fixed, and processed for anti-DBH staining. Scale bar, $5 \mu \mathrm{m}$. $\boldsymbol{B}$, Mean number of DBH fluorescent spots per cells were determined and normalized to cell surface. n.s., Not significant compared with PLSCR-1 ${ }^{+1+}(n=25$ cells). $C$, Representative confocal images of mouse chromaffin cells subjected to anti-DBH internalization assay. Cells were stimulated with $59 \mathrm{~mm} \mathrm{~K}^{+}$for 10 min in the presence of anti-DBH antibodies and maintained for an additional 15 min period in Locke's solution without antibodies to allow DBH/anti-DBH uptake. Cells were fixed, permeabilized, and processed for anti-DBH detection using secondary antibody coupled to Alexa-555 and for tyrosine hydroxylase (TH) staining to identify chromaffin cells. Scale bar, $5 \mu \mathrm{m}$. D. Euclidean distance map analysis of anti-DBH positive vesicles. ${ }^{* *} p<0.001$, compared with PLSCR-1 ${ }^{+/+}$( $n=25$ cells).

full fusion exocytosis and are subsequently internalized through a compensatory endocytosis process, leading to vesicular structures, which do not include plasma membrane proteins (Ceridono et al., 2011). Thus, a tight coupling between calciumregulated exocytosis and compensatory endocytosis exists, but how secretory cells precisely sort granule membrane-associated proteins after fusion and full collapse and how compensatory endocytosis is triggered and regulated remain uninvestigated questions.

Signaling platforms created and maintained in cell membranes by changing the lipid composition and/or asymmetry play an essential role in many aspects of the cell physiology (Ikeda et al., 2006). Cell surface exposure of PS during calcium-regulated secretion has been observed in mast cells (Demo et al., 1999), PC12 cells (Vitale et al., 2001; Malacombe et al., 2006), nerve terminals (Lee et al., 2000), and chromaffin cells (Ceridono et al., 2011). Moreover, externalization of PS has been proposed to regulate various membrane fusion events, including myotube formation, sperm capacitation reaction, and microparticle release (Bailey and Cullis, 1994; Gadella and Harrison, 2000; van den Eijnde et al., 2001; Gonzalez et al., 2009). Yet, the functional importance of cell surface PS exposure for regulated exocytosis remains controversial because exocytosis has been shown to occur both dependently (Kato et al., 2002) or independently (Acharya et al., 2006) of it.

Using chromaffin cells lacking PLSCR-1 expression or expressing the calciuminsensitive PLSCR-1 $1_{\text {D284A }}$ mutant, we show here that (1) secretagogue-evoked exocytosis is accompanied by cell surface PS exposure at the close vicinity of the granule membrane transiently inserted into the plasma membrane; (2) this secretagogueinduced PS externalization requires PLSCR-1; and (3) PLSCR-1 activity and cell surface exposure of PS play no role in exocytosis but are required for efficient granule membrane compensatory endocytosis.

Spatial segregation of PS redistribution How can a lipid redistribution and loss of PS asymmetry be restricted to the periphery of a secretory granule membrane that just merged with the plasma membrane? Our results indicate that $\mathrm{PS}$ redistribution is linked to PLSCR-1 activity in chromaffin cells. However, the subcellular localization of endogenous PLSCR-1 in adrenal chromaffin cells has not been solved. Given its functional importance in secretory granule compensatory endocytosis, PLSCR-1 is expected to localize either at the plasma membrane or at the secretory granule membrane. In human epithelial cells or fibroblasts, PLSCR-1 has been localized to the plasma membrane, the endosomes, and the nucleus (Zhao et al., 1998a; Sun et al., 2002; Wiedmer et al., 2003; Talukder et al, 2012). Accordingly, our data suggest a preferential localization at the plasma membrane. First, the exogenously expressed PLSCR-1 colocalized with the plasma membrane-bound syntaxin-1 and not with the secretory granule marker, DBH (Fig. 2). Second, by performing subcellular fractionation from BON cells culture, a human pancreatic enterochromaffin cell line (Zhang et al., 1995), we detected the presence of endogenous PLSCR-1 in fractions enriched in plasma membrane but not in secretory granules (data not shown). Third, the spatial analysis of cell surface distribution of PS in stimulated chromaffin cells demonstrated that PS exit occurs preferentially at the vicinity but outside the $\mathrm{DBH}$-containing granule membrane fused with the plasma membrane (Fig. 1). If PLSCR-1 is a plasma membrane bound protein, why is it activated only at the proximity of granule fusion sites leading to a patchy externalization of PS? The calcium dependence of PLSCR-1 may contribute to the spatial dis- 

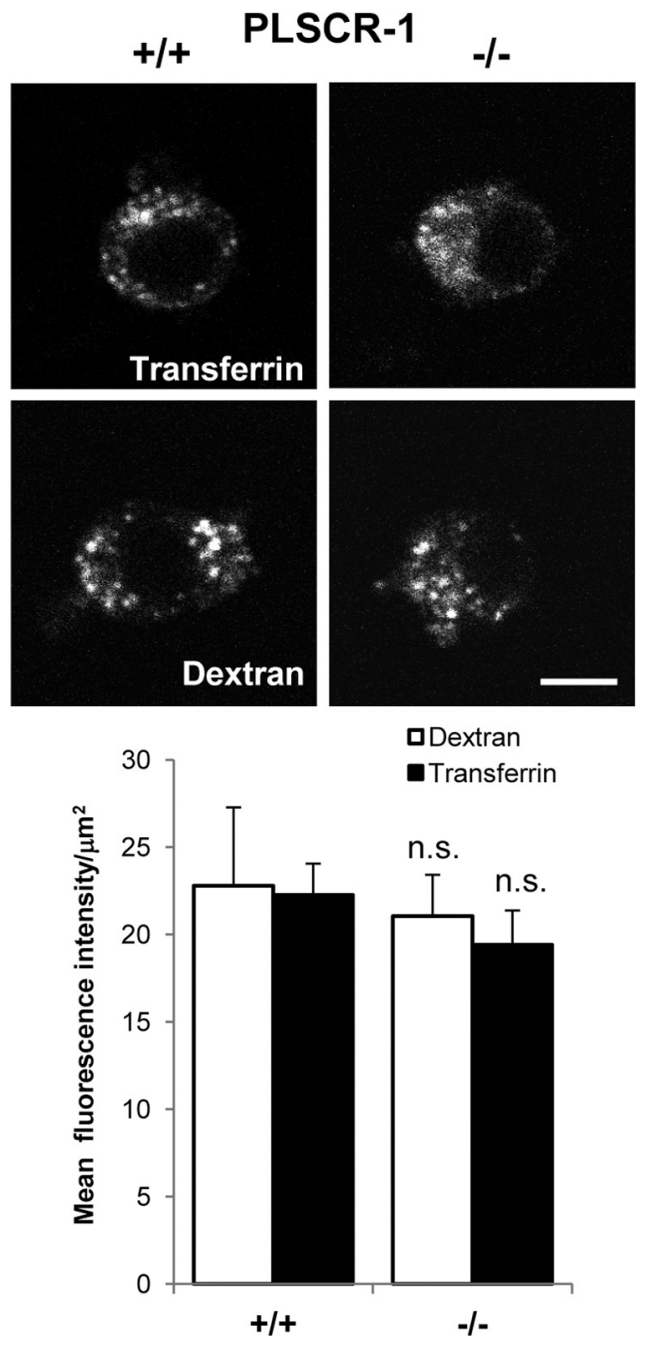

Figure 8. Constitutive endocytosis and fluid-phase uptake are not impaired in PLSCR-1 ${ }^{-/-}$ mouse chromaffin cells. Chromaffin cells were serum starved for $1 \mathrm{~h}$ and incubated for $30 \mathrm{~min}$ in the presence of fluorescent transferrin or $3 \mathrm{kDa}$ dextran. Cells were fixed and imaged with confocal microscope. Scale bar, $5 \mu \mathrm{m}$. The histogram represents the quantification of transferrin and dextran uptake by measuring the mean fluorescent intensity normalized to cell area. n.s., Not significant.

tribution of its activity. Indeed, PLSCR-1 requires $\mathrm{Ca}^{2+}$ for activation, with an apparent affinity of $\sim 10 \mu \mathrm{M}$ (Stout et al., 1998), and activation may therefore occur only at short distances of the exocytotic hot spots where calcium levels can reach 5-10 $\mu \mathrm{M}$ in stimulated chromaffin cells (Klingauf and Neher, 1997; Becherer et al., 2003). Alternatively, we cannot exclude that activation of plasma membrane bound PLSCR-1 may require a granule-associated component, and thus restricting its activation to the sites where granules fuse with the plasma membrane.

\section{Scrambling or not scrambling?}

PLSCR-1 was originally proposed to mediate rapid bidirectional transbilayer movement of phospholipids across the membrane in a $\mathrm{Ca}^{2+}$-dependent manner and thereby collapse phospholipid asymmetry (Basse et al., 1996; Devaux et al., 2006). However, the lipid scrambling activity of PLSCR-1 remains highly controversial. Evidence against a PLSCR-1 phospholipid scrambling activity is the surface PS exposure observed upon activation of platelets from PLSCR-1 $1^{-l-}$ knock-out mice (Zhou et al., 2002). Yet, compensatory mechanism resulting from expression of other PLSCR family proteins or the recently discovered scramblase TMEM16F cannot be excluded (Suzuki et al., 2010). Conversely, red blood cells from a patient with Scott syndrome display defective scrambling but show no abnormalities in any of the PLSCR genes or proteins (Zhou et al., 1998b). Although its scramblase activity per se is questioned, our data clearly indicate that PLSCR-1 is required for the secretagogue-induced PS reorganization at the vicinity of the exocytotic sites in the neuroendocrine chromaffin cells. In our experimental conditions, the lack of PLSCR-1 cannot be bypassed by other PLSCR isoforms or the $\mathrm{Ca}^{2+}$-dependent scramblase TMEM16F (Suzuki et al., 2010). Thus, PLSCR-1 might be implicated in a signaling pathway leading to a specific PS redistribution, or it might induce during the secretory granule fusion event a general lipidic reorganization reflected by the cell surface exposure of PS. Interestingly, in systematic mapping of protein-protein interaction of the human proteome, PLSCR-1 has been found to interact with the inositol hexakisphosphate kinase 2 (IP6K2) (Rual et al., 2005). IP6Ks generate highly phosphorylated inositol polyphosphate (referred to as IP7 and IP8). IP6K1, but not IP6K2, modulates exocytotic activity of $\beta$-pancreatic cells. Whether it might be involved in compensatory endocytosis has not been investigated (Illies et al., 2007). In any case, the exact nature and the underlying mechanism of the lipid remodelling induced by PLSCR-1 at the interphase between secretory granule and plasma membrane are challenging questions that remain to be investigated.

\section{PS distribution and compensatory endocytosis}

We show here for the first time that secretagogue-induced PS exposure is a key step for recycling secretory granule membrane after exocytosis. In secreting chromaffin cells lacking PLSCR-1 activity or expressing the calcium-insensitive PLSCR-1 $1_{\mathrm{D} 284 \mathrm{~A}}$, PS externalization is blocked, unchanging the exocytotic response but inhibiting the subsequent compensatory endocytosis. It seems intriguing that the calcium-insensitive PLSCR- $1_{\mathrm{D} 284 \mathrm{~A}} \mathrm{mu}-$ tant behaves as a dominant-negative mutant. A possible explanation is that PLSCR proteins form dimers (Rual et al., 2005), as observed for several proteins containing EF-Hand domains (Yap et al., 1999). By interacting with endogenous PLSCR-1, the PLSCR-1 $1_{\mathrm{D} 284 \mathrm{~A}}$ mutant might prevent proper calcium activation of PLSCR-1. Interestingly, PLSCR-1 is specifically involved in compensatory endocytosis in neuroendocrine cells because constitutive endocytotic pathways, such as receptor-mediated endocytosis of transferrin or fluid-phase uptake, are not affected in PLSCR-1 $1^{-/-}$mice. Does PLSCR-1 play a role in synaptic vesicle endocytosis in neurons? The question is worth exploring because several $\mathrm{Ca}^{2+}$-dependent scramblase proteins, including PLSCR-1 and TMEM16F, have been detected in neurons (Rami et al., 2003; Acharya et al., 2006; Gritli-Linde et al., 2009) and transbilayer phospholipid redistribution has been associated with neurotransmitter release (Lee et al., 2000).

How may cell surface PS control compensatory endocytosis? As previously discussed, externalization of PS may either reflect the loss of PS asymmetry and/or reveal a profound lipid reorganization or recomposition to create a microdomain. Hence, in red blood cells, loss of phospholipid asymmetry can modify membrane mechanical stability (Manno et al., 2002). Moreover, formation of lipid raft microdomain is necessary for the structural and spatial organization of the exocytotic machinery, including SNARE complex assembly (Chasserot-Golaz et al., 2005; Salaun et al., 2005; Puri and Roche, 2006). Therefore, a possible scenario is that a local reorganization of lipids surrounding the granule membrane transiently inserted within the plasma mem- 
brane might serve as a signal to retain granule components and preserve the integrity of the granule membrane for compensatory endocytosis in neuroendocrine cells.

Alternatively, as an anionic phospholipid, PS confers negative charges, and its redistribution may contribute to the recruitment of proteins required for compensatory endocytosis by changing the membrane surface charge (Elliott et al., 2005; Yeung et al., 2008; Das et al., 2012). For example, modification in PS distribution has been shown to be critical for the recruitment of the tyrosine-kinase c-Src during phagosome maturation as well as for the membrane targeting of Rho GTPases members during cell polarity establishment (Fairn et al., 2011; Das et al., 2012). Moreover, PS has been shown to directly bind various proteins involved in exocytosis of large dense-core granules, such as annexin-A2, rabphilin, DOC 2, or synaptotagmin (Stace and Ktistakis, 2006). Thus, the local decrease in PS concentration at the inner leaflet of the plasma membrane could represent a signal to switch from exocytosis to endocytosis, by permitting the release of exocytotic components and the recruitment of molecules and specific adaptors dedicated to endocytosis. In line with this idea, despite no changes in total levels of endocytotic proteins, such as clathrin, dynamin-2, or $\beta$-adaptin in cells lacking PLSCR-1 (data not shown), our preliminary observations suggest that clathrin recruitment to the granule membrane transiently inserted into the plasma membrane, which is required for compensatory endocytosis (Ceridono et al., 2011), is reduced. This observation merits further investigations to determine the specific relationship between PS translocation and the recruitment of compensatory endocytotic machinery.

In conclusion, activation of secretion in neuroendocrine cells triggers a PLSCR-1-dependent outward translocation of PS around the exocytotic granule membrane. Although this lipid reorganization does not regulate the exocytotic process per se, we show here for the first time that it appears as an essential step for compensatory endocytosis. Resolving the mechanistic details of this lipid reorganization and its downstream molecular cascades to selectively retrieve secretory granule membranes in neuroendocrine cells is the next challenging question.

\section{References}

Acharya U, Edwards MB, Jorquera RA, Silva H, Nagashima K, Labarca P, Acharya JK (2006) Drosophila melanogaster Scramblases modulate synaptic transmission. J Cell Biol 173:69-82. CrossRef Medline

Bailey AL, Cullis PR (1994) Modulation of membrane fusion by asymmetric transbilayer distributions of amino lipids. Biochemistry 33:12573-12580. CrossRef Medline

Bang DY, Ahn Ej, Moon MH (2007) Shotgun analysis of phospholipids from mouse liver and brain by nanoflow liquid chromatography/tandem mass spectrometry. J Chromatogr B Analyt Technol Biomed Life Sci 852: 268-277. CrossRef Medline

Bassé F, Stout JG, Sims PJ, Wiedmer T (1996) Isolation of an erythrocyte membrane protein that mediates $\mathrm{Ca} 2+$-dependent transbilayer movement of phospholipid. J Biol Chem 271:17205-17210. CrossRef Medline

Becherer U, Moser T, Stühmer W, Oheim M (2003) Calcium regulates exocytosis at the level of single vesicles. Nat Neurosci 6:846-853. CrossRef Medline

Bligh EG, Dyer WJ (1959) A rapid method of total lipid extraction and purification. Can J Biochem Physiol 37:911-917. CrossRef Medline

Ceridono M, Ory S, Momboisse F, Chasserot-Golaz S, Houy S, Calco V, Haeberlé AM, Demais V, Bailly Y, Bader MF, Gasman S (2011) Selective recapture of secretory granule components after full collapse exocytosis in neuroendocrine chromaffin cells. Traffic 12:72-88. CrossRef Medline

Chasserot-Golaz S, Vitale N, Umbrecht-Jenck E, Knight D, Gerke V, Bader MF (2005) Annexin 2 promotes the formation of lipid microdomains required for calcium-regulated exocytosis of dense-core vesicles. Mol Biol Cell 16:1108-1119. CrossRef Medline
Das A, Slaughter BD, Unruh JR, Bradford WD, Alexander R, Rubinstein B, Li R (2012) Flippase-mediated phospholipid asymmetry promotes fast Cdc42 recycling in dynamic maintenance of cell polarity. Nat Cell Biol 14:304-310. CrossRef Medline

Demo SD, Masuda E, Rossi AB, Throndset BT, Gerard AL, Chan EH, Armstrong RJ, Fox BP, Lorens JB, Payan DG, Scheller RH, Fisher JM (1999) Quantitative measurement of mast cell degranulation using a novel flow cytometric annexin-V binding assay. Cytometry 36:340-348. CrossRef Medline

Devaux PF, López-Montero I, Bryde S (2006) Proteins involved in lipid translocation in eukaryotic cells. Chem Phys Lipids 141:119-132. CrossRef Medline

Elliott JI, Surprenant A, Marelli-Berg FM, Cooper JC, Cassady-Cain RL, Wooding C, Linton K, Alexander DR, Higgins CF (2005) Membrane phosphatidylserine distribution as a non-apoptotic signalling mechanism in lymphocytes. Nat Cell Biol 7:808-816. CrossRef Medline

Espinoza FA, Oliver JM, Wilson BS, Steinberg SL (2012) Using hierarchical clustering and dendrograms to quantify the clustering of membrane proteins. Bull Math Biol 74:190-211. CrossRef Medline

Fairn GD, Hermansson M, Somerharju P, Grinstein S (2011) Phosphatidylserine is polarized and required for proper Cdc42 localization and for development of cell polarity. Nat Cell Biol 13:1424-1430. CrossRef Medline

Gadella BM, Harrison RA (2000) The capacitating agent bicarbonate induces protein kinase A-dependent changes in phospholipid transbilayer behavior in the sperm plasma membrane. Development 127:2407-2420. Medline

Gasman S, Chasserot-Golaz S, Popoff MR, Aunis D, Bader MF (1997) Trimeric $\mathrm{G}$ proteins control exocytosis in chromaffin cells: Go regulates the peripheral actin network and catecholamine secretion by a mechanism involving the small GTP-binding protein Rho. J Biol Chem 272:2056420571. CrossRef Medline

Gonzalez LJ, Gibbons E, Bailey RW, Fairbourn J, Nguyen T, Smith SK, Best KB, Nelson J, Judd AM, Bell JD (2009) The influence of membrane physical properties on microvesicle release in human erythrocytes. PMC Biophys 2:7. CrossRef Medline

Gritli-Linde A, Vaziri Sani F, Rock JR, Hallberg K, Iribarne D, Harfe BD, Linde A (2009) Expression patterns of the Tmem16 gene family during cephalic development in the mouse. Gene Expr Patterns 9:178-191. CrossRef Medline

Houjou T, Yamatani K, Imagawa M, Shimizu T, Taguchi R (2005) A shotgun tandem mass spectrometric analysis of phospholipids with normal-phase and/or reverse-phase liquid chromatography/electrospray ionization mass spectrometry. Rapid Commun Mass Spectrom 19:654-666. CrossRef Medline

Ikeda M, Kihara A, Igarashi Y (2006) Lipid asymmetry of the eukaryotic plasma membrane: functions and related enzymes. Biol Pharm Bull 29: 1542-1546. CrossRef Medline

Illies C, Gromada J, Fiume R, Leibiger B, Yu J, Juhl K, Yang SN, Barma DK, Falck JR, Saiardi A, Barker CJ, Berggren PO (2007) Requirement of inositol pyrophosphates for full exocytotic capacity in pancreatic beta cells. Science 318:1299-1302. CrossRef Medline

Kato N, Nakanishi M, Hirashima N (2002) Transbilayer asymmetry of phospholipids in the plasma membrane regulates exocytotic release in mast cells. Biochemistry 41:8068-8074. CrossRef Medline

Klingauf J, Neher E (1997) Modeling buffered Ca2+ diffusion near the membrane: implications for secretion in neuroendocrine cells. Biophys J 72:674-690. CrossRef Medline

Kreft M, Gasman S, Chasserot-Golaz S, Kuster V, Rupnik M, Sikdar SK, Bader M, Zorec R (1999) The heterotrimeric Gi(3) protein acts in slow but not in fast exocytosis of rat melanotrophs. J Cell Sci 112:4143-4150. Medline

Lee D, Hirashima N, Kirino Y (2000) Rapid transbilayer phospholipid redistribution associated with exocytotic release of neurotransmitters from cholinergic nerve terminals isolated from electric ray Narke japonica. Neurosci Lett 291:21-24. CrossRef Medline

Malacombe M, Ceridono M, Calco V, Chasserot-Golaz S, McPherson PS, Bader MF, Gasman S (2006) Intersectin-1L nucleotide exchange factor regulates secretory granule exocytosis by activating Cdc42. EMBO J 25: 3494-3503. CrossRef Medline

Manno S, Takakuwa Y, Mohandas N (2002) Identification of a functional role for lipid asymmetry in biological membranes: phosphatidylserine- 
skeletal protein interactions modulate membrane stability. Proc Natl Acad Sci U S A 99:1943-1948. CrossRef Medline

Momboisse F, Lonchamp E, Calco V, Ceridono M, Vitale N, Bader MF, Gasman S (2009) betaPIX-activated Racl stimulates the activation of phospholipase $\mathrm{D}$, which is associated with exocytosis in neuroendocrine cells. J Cell Sci 122:798-806. CrossRef Medline

Mosharov EV, Sulzer D (2005) Analysis of exocytotic events recorded by amperometry. Nat Methods 2:651-658. CrossRef Medline

Opazo F, Rizzoli SO (2010) The fate of synaptic vesicle components upon fusion. Commun Integr Biol 3:427-429. CrossRef Medline

Opazo F, Punge A, Bückers J, Hoopmann P, Kastrup L, Hell SW, Rizzoli SO (2010) Limited intermixing of synaptic vesicle components upon vesicle recycling. Traffic 11:800-812. CrossRef Medline

Puri N, Roche PA (2006) Ternary SNARE complexes are enriched in lipid rafts during mast cell exocytosis. Traffic 7:1482-1494. CrossRef Medline

Rami A, Sims J, Botez G, Winckler J (2003) Spatial resolution of phospholipid scramblase 1 (PLSCR1), caspase-3 activation and DNA-fragmentation in the human hippocampus after cerebral ischemia. Neurochem Int 43:79-87. CrossRef Medline

Rual JF, Venkatesan K, Hao T, Hirozane-Kishikawa T, Dricot A, Li N, Berriz GF, Gibbons FD, Dreze M, Ayivi-Guedehoussou N, Klitgord N, Simon C, Boxem M, Milstein S, Rosenberg J, Goldberg DS, Zhang LV, Wong SL, Franklin G, Li S, et al. (2005) Towards a proteome-scale map of the human protein-protein interaction network. Nature 437:1173-1178. CrossRef Medline

Salaün C, Gould GW, Chamberlain LH (2005) Lipid raft association of SNARE proteins regulates exocytosis in PC12 cells. J Biol Chem 280: 19449-19453. CrossRef Medline

Schonn JS, van Weering JR, Mohrmann R, Schlüter OM, Südhof TC, de Wit H, Verhage M, Sørensen JB (2010) Rab3 proteins involved in vesicle biogenesis and priming in embryonic mouse chromaffin cells. Traffic 11:1415-1428. CrossRef Medline

Sims PJ, Wiedmer T (2001) Unraveling the mysteries of phospholipid scrambling. Thromb Haemost 86:266-275. Medline

Smrz D, Lebduska P, Dráberova L, Korb J, Dráber P (2008) Engagement of phospholipid scramblase 1 in activated cells: implication for phosphatidylserine externalization and exocytosis. J Biol Chem 283:10904-10918. CrossRef Medline

Stace CL, Ktistakis NT (2006) Phosphatidic acid- and phosphatidylserinebinding proteins. Biochim Biophys Acta 1761:913-926. CrossRef Medline

Stout JG, Zhou Q, Wiedmer T, Sims PJ (1998) Change in conformation of plasma membrane phospholipid scramblase induced by occupancy of its $\mathrm{Ca}^{2+}$ binding site. Biochemistry 37:14860-14866. CrossRef Medline

Sun J, Zhao J, Schwartz MA, Wang JY, Wiedmer T, Sims PJ (2001) c-Abl tyrosine kinase binds and phosphorylates phospholipid scramblase 1. J Biol Chem 276:28984-28990. CrossRef Medline

Sun J, Nanjundan M, Pike LJ, Wiedmer T, Sims PJ (2002) Plasma membrane phospholipid scramblase 1 is enriched in lipid rafts and interacts with the epidermal growth factor receptor. Biochemistry 41:6338-6345. CrossRef Medline

Suzuki J, Umeda M, Sims PJ, Nagata S (2010) Calcium-dependent phospholipid scrambling by TMEM16F. Nature 468:834-838. CrossRef Medline

Talukder AH, Bao M, Kim TW, Facchinetti V, Hanabuchi S, Bover L, Zal T, Liu YJ (2012) Phospholipid Scramblase 1 regulates Toll-like receptor 9-mediated type I interferon production in plasmacytoid dendritic cells. Cell Res 22:1129-1139. CrossRef Medline
Umbrecht-Jenck E, Demais V, Calco V, Bailly Y, Bader MF, Chasserot-Golaz S (2010) S100A10-mediated translocation of annexin-A2 to SNARE proteins in adrenergic chromaffin cells undergoing exocytosis. Traffic 11:958-971. CrossRef Medline

Van den Eijnde SM, van den Hoff MJ, Reutelingsperger CP, van Heerde WL, Henfling ME, Vermeij-Keers C, Schutte B, Borgers M, Ramaekers FC (2001) Transient expression of phosphatidylserine at cell-cell contact areas is required for myotube formation. J Cell Sci 114:3631-3642. Medline

Van Meer G, Voelker DR, Feigenson GW (2008) Membrane lipids: where they are and how they behave. Nat Rev Mol Cell Biol 9:112-124. CrossRef Medline

Vitale N, Caumont AS, Chasserot-Golaz S, Du G, Wu S, Sciorra VA, Morris AJ, Frohman MA, Bader MF (2001) Phospholipase D1: a key factor for the exocytotic machinery in neuroendocrine cells. EMBO J 20:2424-2434. CrossRef Medline

Wang N, Kwan C, Gong X, de Chaves EP, Tse A, Tse FW (2010) Influence of cholesterol on catecholamine release from the fusion pore of large dense core chromaffin granules. J Neurosci 30:3904-3911. CrossRef Medline

Wiedmer T, Zhao J, Nanjundan M, Sims PJ (2003) Palmitoylation of phospholipid scramblase 1 controls its distribution between nucleus and plasma membrane. Biochemistry 42:1227-1233. CrossRef Medline

Yap KL, Ames JB, Swindells MB, Ikura M (1999) Diversity of conformational states and changes within the EF-hand protein superfamily. Proteins 37:499-507. CrossRef Medline

Yeung T, Gilbert GE, Shi J, Silvius J, Kapus A, Grinstein S (2008) Membrane phosphatidylserine regulates surface charge and protein localization. Science 319:210-213. CrossRef Medline

Zhang J, Leiderman K, Pfeiffer JR, Wilson BS, Oliver JM, Steinberg SL (2006) Characterizing the topography of membrane receptors and signaling molecules from spatial patterns obtained using nanometer-scale electrondense probes and electron microscopy. Micron 37:14-34. CrossRef Medline

Zhang T, Townsend CM Jr, Udupi V, Yanaihara N, Rajaraman S, Beauchamp RD, Ishizuka J, Evers BM, Gomez G, Thompson JC, et al. (1995) Phorbol ester-induced alteration in the pattern of secretion and storage of chromogranin A and neurotensin in a human pancreatic carcinoid cell line. Endocrinology 136:2252-2261. CrossRef Medline

Zhao J, Zhou Q, Wiedmer T, Sims PJ (1998a) Level of expression of phospholipid scramblase regulates induced movement of phosphatidylserine to the cell surface. J Biol Chem 273:6603-6606. CrossRef Medline

Zhao J, Zhou Q, Wiedmer T, Sims PJ (1998b) Palmitoylation of phospholipid scramblase is required for normal function in promoting $\mathrm{Ca}^{2+}$ activated transbilayer movement of membrane phospholipids. Biochemistry 37:6361-6366. CrossRef Medline

Zhou Q, Sims PJ, Wiedmer T (1998a) Identity of a conserved motif in phospholipid scramblase that is required for $\mathrm{Ca}^{2+}$-accelerated transbilayer movement of membrane phospholipids. Biochemistry 37:2356-2360. CrossRef Medline

Zhou Q, Sims PJ, Wiedmer T (1998b) Expression of proteins controlling transbilayer movement of plasma membrane phospholipids in the B lymphocytes from a patient with Scott syndrome. Blood 92:1707-1712. Medline

Zhou Q, Zhao J, Wiedmer T, Sims PJ (2002) Normal hemostasis but defective hematopoietic response to growth factors in mice deficient in phospholipid scramblase 1. Blood 99:4030-4038. CrossRef Medline 